\title{
IMMUNOHISTOCHEMICAL ASSESSMENT OF MUCOSAL CYTOKINE PROFILE IN ACETIC ACID EXPERIMENTAL COLITIS
}

Pedro L. Bertevello, Ângela Flávia Logullo, Sueli Nonogaki, Fabio M. Campos, Valcir Chiferi, Claudia C. Alves, Raquel S. Torrinhas, Joaquim José GamaRodrigues, and Dan L. Waitzberg

Bertevello PL, Logullo AF, Nonogaki S, Campos FM, Chiferi V, Torrinhas CS et al. Immunohistochemical assessment of mucosal cytokine profile in acetic acid experimental colitis. Clinics. 2005;60(4):277-86.

Experimental colitis induced by acetic acid has been used extensively as a model for intestinal inflammatory disease. Colonic tissue lesions of intestinal inflammatory disease patients seem to be related to the increased local production of proinflammatory cytokines (IL-1, IL-6, TNF-D, and IFN-J).

PURPOSE: To assess the cytokine expression pattern identified through immunohistochemistry in colonic mucosa after experimental colitis induced by acetic acid and establish the relationship between this pattern and the presence of macroscopic lesions.

MATERIALS AND METHODS: Adult male Wistar rats $(\mathrm{n}=39)$ were divided at random into 4 groups: NC45 and NC24 (control without colitis; sacrificed at 45 minutes and 24 hours, respectively); and WC45 and WC24 (with experimental colitis induced by acetic acid; sacrificed at 45 minutes and 24 hours, respectively). Macroscopic and microscopic alterations in colonic tissue were evaluated, and cytokine expression was assessed through immunohistochemistry.

RESULTS: After 24 hours, IL-1 expression was greater in the groups with colitis when compared to the groups without colitis. IL-4 expression was higher in the WC45 group. There was an increase in both INF-J and IL-6 related to the presence of necrosis of the colonic mucosa in the groups with colitis for both periods evaluated.

CONCLUSION: The immunohistochemical technique was efficient for the analysis of various cytokine expressions in the colonic tissue. There was an increase in the IL-1 pro-inflammatory cytokines as well as in IL-6 and IFN-J associated with the presence of colonic necrosis. Experimental colitis induced by acetic acid is a useful model for the development of studies assessing the role of cytokines in the inflammation of mucosa as well as anti-cytokine therapies.

KEYWORDS: Cytokines. Rats. Inflammatory colitis. Immunohistochemistry. Necrosis.

The role of cytokines in the immune system within the colonic mucosa has been extensively assessed in both experimental and clinical studies. ${ }^{1,2}$ In such studies, cytokines are considered determinants of the nature of the mucosal immune response. Cytokines synthesized and secreted by defense cells of the lamina propria either induce, amplify and prolong (pro-inflammatory), or attenuate (anti-inflammatory) the inflammatory process. ${ }^{3}$ An imbalance has been

Department of Gastroenterology, Faculty of Medicine, University of São Paulo - São Paulo/SP, Brazil.

E-mail: metanutri@usp.br

Received for publication on December 20, 2004.

Accepted for publication on February 14, 2005. found between pro-inflammatory and anti-inflammatory cytokines in intestinal inflammatory disease (IID), with increased levels of interleukin (IL) pro-inflammatory cytokines IL-1, IL-6, IL-8, and tumor necrosis factor (TNFD). ${ }^{1,2,4,5}$ A greater IL-1:IL-1ra ratio has also been shown in mucosae of patients with Crohn's disease, ulcerative colitis, diverticulitis, and infectious colitis..$^{6-8}$

The increase of pro-inflammatory cytokines among IID patients can be accompanied by local and systemic tissue damage, indicating an important role of these inflammatory mediators in determining the severity of the disease. Local increases occur in microvascular permeability with conse- 
quent vascular congestion and edema; ${ }^{9}$ production of other cytokines is also induced, as well as activation of the vascular endothelium, recruitment of inflammatory cells, and activation of the coagulation system. ${ }^{10}$

Attempts to reproduce experimental inflammatory disease in the colon have generated a number of acute or chronic inflammation models. ${ }^{11}$ Currently, models of exogenous induction of experimental colitis have been used more extensively due to their technical simplicity, reproducibility, and lower cost. The most frequently used agents are acetic acid, ${ }^{12-18}$ ethanol, ${ }^{19,20}$ dextran sodium sulfate, ${ }^{21}$ indomethacin, ${ }^{22}$ and TNBS/ethanol. ${ }^{18,23-26}$

While the IID inflammatory process in humans is probably the result of a disordered immunological activation, experimental colitis induced by exogenous agents is unleashed, at least at first, by local tissue lesions. Nonetheless, the inhibition of pro-inflammatory cytokines or the administration anti-inflammatory cytokines in experimental colitis models induced by dextran sodium sulfate (DSS) or by trinitrobenzene sulfonic acid (TNBS) reduces colonic inflammation, indicating that these models seem to reproduce the increase in the pro-inflammatory cytokine expression found in IID patients. ${ }^{27-29}$

The use of acetic acid provokes nonspecific inflammation similar to ulcerative colitis, ${ }^{12,14,15,30}$ with easily reproducible lesions and low mortality. ${ }^{14}$ An understanding of the cytokine expression pattern in the colonic mucosa after the induction of colitis by endoanal infusion with acetic acid, as well as its influence on the appearance or aggravation of consequent macroscopic lesions in the colonic mucosa, could contribute to the comprehension of its accuracy as a model for human colitis with regard to immunological alterations.

In experimental models, the appearance of inflammatory cytokines occurs in distinct periods. Some models present elevations in cytokine levels just minutes after the aggressor stimulus, whereas in others, the elevations occur at a later time. ${ }^{9,31,32}$ Cytokine kinetics should therefore be considered in studies that assess cytokine expression.

Cytokine analysis is generally carried out in a systematic fashion. The development of an immunohistochemical technique applied to the colonic tissue allows the direct demonstration of cells that express different cytokines at the site of the aggression.

The objective of the present study was to assess the cytokine expression pattern in colonic tissue after the induction of experimental colitis through endoanal infusion of acetic acid, and to relate the cytokine to the presence of clinical lesions characteristic of intestinal inflammatory disease, using an immunohistochemical technique developed specifically for this purpose.

\section{MATERIALS AND METHODS}

\section{Animals}

A total of 39 adult male Wistar rats (Rattus norvegicus albinus), weighing between 250 and 300 grams were acquired from the Central Animal Breeding Center of the Faculty of Medicine, University of São Paulo Medical School (FMUSP). The animals were housed in individual metabolic cages, with water and pellet ration ad libitum. They were kept at room temperature and under diurnal light cycles at the Laboratório de Fisiologia e Distúrbios Esfincterianos, FMUSP - LIM 35.

\section{Elimination of intestinal parasites}

Before initiating the experimental procedures, all animals were treated with two vermifuges: Praziquantel (Cestox ${ }^{\circledR}$ Merck Sharp Dohme) at a dosage of $25 \mathrm{mg} / \mathrm{kg}$ of weight; and Ivermectin/Pirantel (Ivomec ${ }^{\circledR}$ - Merck Sharp Dohme) at $2.0 \mathrm{mg} / \mathrm{kg}$ of weight. Both vermifuges were mixed with $10 \%$ propylene glycol and administered orally in 3 doses at 7day intervals for 2 weeks before the experiment.

\section{Colitis induction}

The animals were randomly divided into 2 groups-a group for induction of experimental colitis and a control group. In the colitis group, induction of the inflammatory process of the colon was achieved through a $0.5 \mathrm{~mL}$ rectal injection of $10 \%$ acetic acid through a $1 \mathrm{~mL}$ sterile syringe coupled to a No. 6 polyethylene catheter, externally lubricated with lidocaine gel. The catheter was introduced anally to a distance of $7 \mathrm{~cm}$, in accordance with the standard method of this laboratory. ${ }^{18}$ The animals in the control group received an endoanal infusion of $1 \mathrm{~mL}$ normal saline solution.

\section{Experimental groups}

After the endoanal infusion of acetic acid (experimental group) or physiological solution (control group), the animals in both groups were subdivided for sacrifice at $45 \mathrm{~min}$ utes or 24 hours after colitis induction. Thus, the resulting subgroups were composed as follows:

NC45-Animals without colitis, sacrificed 45 minutes after endoanal infusion of saline solution $(\mathrm{n}=9)$;

NC24-Animals without colitis, sacrificed 24 hours after endoanal infusion of saline solution $(n=10)$;

WC45-Animals with colitis, sacrificed 45 minutes after endoanal infusion of acetic acid $(n=10)$;

WC24-Animals with colitis, sacrificed 24 hours after endoanal infusion of acetic acid $(n=10)$. 


\section{Collection of biological material and sacrifice}

Prior to the sacrifice, the animals were anesthetized through an intraperitoneal injection of $100 \mathrm{mg} / \mathrm{kg}$ body weight of ketamine chlorohydrate (Ketalar® - Parke-Davis). After anesthesia, a laparotomy was performed for inspection of the abdominal cavity and complete resection of the large intestine (from the rectum to the transition with the small intestine). Animals were subsequently sacrificed by an anesthetic overdose. The colons were rinsed with $20 \mathrm{~mL}$ of saline solution and opened longitudinally for macroscopic analysis, collection of biological samples, microscopic analysis and determination of cytokine expression.

\section{Macroscopic analysis of the colon}

Macroscopic alterations in the colonic mucosa were classified into 5 grades, according to the system described by Moraes $^{14,15}$, modified by Campos ${ }^{18}$ (Table 1 ).

The presence of the following alterations was investigated: dilatation and thickening of the colon walls or small intestine, the formation of adherences to the small intestine or the epiploon; thickening of the mesentery (mesenteritis); and perforation of the colon. During macroscopic exam of the colonic tissue, additional attention was given to the serosa that covers the length of the organ. Disorders were identified, such as segmental hyperemia of the colon, characterized by a focal increase of red coloration and the presence of vascular ectasia; edema of the colonic wall, characterized by a thickening of the wall by liquid; ischemia, characterized by pallor in the serosa that covers the colon; and necrosis, characterized by a change in the coloration of the colon segment.

Table 1 - Classification of macroscopic alterations in the colonic mucosa

\begin{tabular}{cl}
\hline GRADE & MACROSCOPIC FEATURES \\
\hline 0 & $\begin{array}{l}\text { Preserved mucosal layer, folding with } \\
\text { normal aspect }\end{array}$ \\
\hline I & $\begin{array}{l}\text { Edema, congestion and reddish areas } \\
\text { without superficial ulceration }\end{array}$ \\
\hline II & $\begin{array}{l}\text { Linear superficial ulcerations (7-15 mm); } \\
\text { areas with depressed, reddish, or darker } \\
\text { mucosal, granular bottom }\end{array}$ \\
\hline III & $\begin{array}{l}\text { Ulcerated area (15 to 45 mm) with irregular } \\
\text { bottom, granular with rounded shaped } \\
\text { island of normal or edematous mucosa } \\
\text { among ulcerated mucosa }\end{array}$ \\
& $\begin{array}{l}\text { Extensive, irregular and multiple ulcers } \\
\text { (>45 mm); thinned intestinal wall; granular } \\
\text { irregular bottom. }\end{array}$ \\
\hline IV &
\end{tabular}

\section{Microscopic analysis of the colon}

After macroscopic assessment of the mucosa, 2 samples of $4 \mathrm{~cm}$ each were taken from the colon segments and identified as fragments A and B. Fragment A was harvested approximately $5 \mathrm{~cm}$ from the distal edge where the macroscopic alterations caused by the inflammatory process were located. Fragment B was collected from the more proximal region, $5 \mathrm{~cm}$ above the macroscopically altered region, containing macroscopically normal mucosa. The selected samples were separated into previously labeled bottles and fixed in $10 \%$ buffered formalin and later embedded in paraffin. Thin sections $(3 \mu \mathrm{m})$ were cut from these blocks and mounted on histological slides. One slide was stained with hematoxylin and eosin for histopathological evaluation. The other slides to be used for the immunohistochemical reactions were previously treated with 3-aminopropyltriethoxysilane (Sigma-A3648, EUA).

Histological analysis of the intestinal morphology emphasized alterations regarding the integrity and inflammation of colonic mucosa and submucosa, the presence of ulcers, and tissue necrosis. According to our previous results, ${ }^{18}$ the histological variables evaluated were: presence of reactive lymphoid hyperplasia (considered as focal aggregate of lymphoid inflammatory cells in the lamina propria); epithelial exulceration (superficial or partial exfoliation of colonic epithelial cells without complete ulceration); ulceration (loss of epithelial layer, covered by fibrin and neutrophilic debris, sometimes with exposition of submucosa and muscular layer); presence of inflammatory infiltrate in the intestinal wall (infiltrate extension that was restricted to submucosa, to the muscular layer, or present through the intestinal wall); and finally presence of transmural necrosis (death of cellular components of all layers of the intestinal wall). Exulceration, ulcer, and transmural necrosis reflect progressive categorization of intestinal involvement. All results were stored in an individual data file, and later correlated to other macroscopic and immunohistochemical results.

\section{Analysis of cytokine expression in the colon}

The following cytokines were evaluated in the present study: IL-1, IL-4, IL-6, IFN-J, and TNF-D. To determine cytokine expression in the colonic mucosa, an immunohistochemical technique was initially standardized at the Immunohistochemistry Laboratory of the Division of Pathology of Instituto Adolfo Lutz (São Paulo, Brazil) and resulted in the following protocol:

The histological samples underwent standard processing and were embedded in paraffin. Tissue sections were adhered 
to glass slides treated with 3-aminopropyltriethoxysilane, were deparaffinized, and then were rehydrated. Tissue sections from 7 blocks from each animal were prepared.

For antigen recuperation, a humid heat technique was used with a pressure cooker $\left(\right.$ Eterna $^{\circledR}$, Nigro) and a $10 \mathrm{mM}$ citric acid solution (J.T.Baker-0118-01, Mexico) at $6.0 \mathrm{pH}$ for 4 minutes. The samples were rinsed in running water and distilled water.

The natural endogenous peroxidase was blocked with four 5-minute baths of hydrogen peroxide (20 volumes), and the slides were rinsed in running water and PBS buffer.

The primary specific antibodies for the cytokines studied were diluted 1:300 with PBS for anti-rIL-1E and 1:30 for anti-rIL-4, anti-rIL-6, anti-rIFN-J, and anti-rTNF-D. Slides were incubated with primary antibodies in a chamber at $4{ }^{\circ} \mathrm{C}$.

After incubation, the slides were processed by 3 rinses in PBS buffer and incubated for 30 minutes at $37^{\circ} \mathrm{C}$ with the biotinylated secondary antibody (Vector-BA5000, USA) diluted 1:500 with PBS buffer $+0.1 \%$ saponin.

Three additional rinses with PBS buffer preceded incubation with strept-avidin-peroxidase (StreptABComplex/ HRP - Dako A/S-K0377, Denmark), diluted at a proportion of $1: 200$ (PBS $+0.1 \%$ saponin), for 30 minutes at $37^{\circ} \mathrm{C}$.

Positive revelation of the cytokines was achieved by a 5 -minute incubation at $37^{\circ} \mathrm{C}$ with $60 \mathrm{mg} \%$ of chromogen 3,3'-diaminobenzidine tetrahydrochloride (DAB - SigmaD5637, USA).

Counterstaining with Harris' hematoxylin for 1 minute was followed by an additional rinsing in running water and distilled water, and differentiation in ammoniacal water.

Dehydration of the histological sections proceeded with increasing concentrations of alcohol and xylol for the final mounting of the slides with cover glass and Entellan (Merck-7961, Germany).

The efficiency of the immunohistochemical reaction was verified with negative and positive controls. Each slide submitted to immunohistochemical assay had two $5 \mathrm{~mm}$ copies; one received the studied antibody, and the other received bone serum albumin as negative control. Positive controls were amygdalitis tissue blocks.

\section{Evaluation of cytokine expression of the immunohistochemical reaction}

The slides resulting from the immunohistochemical reaction were evaluated individually and independently by two observers in a double-blind manner. Each observer defined 10 fields in an optical microscope (NIKON - JAPAN), at a magnification of 400x, in areas of greater concentration of positive inflammatory cells. In each field, the inflammatory cells in the corium with distinctive strong positivity for the immunohistochemical reaction were counted. Stromal and epithelial cells were not considered. The evaluation resulted in 10 absolute values that led to the absolute number per slide after calculating the arithmetic mean. Finally, the mean of the two observers was used for the final result of the reaction. Figure 1 shows positive and negative examples of the immunohistochemical reactions for TNF-D.
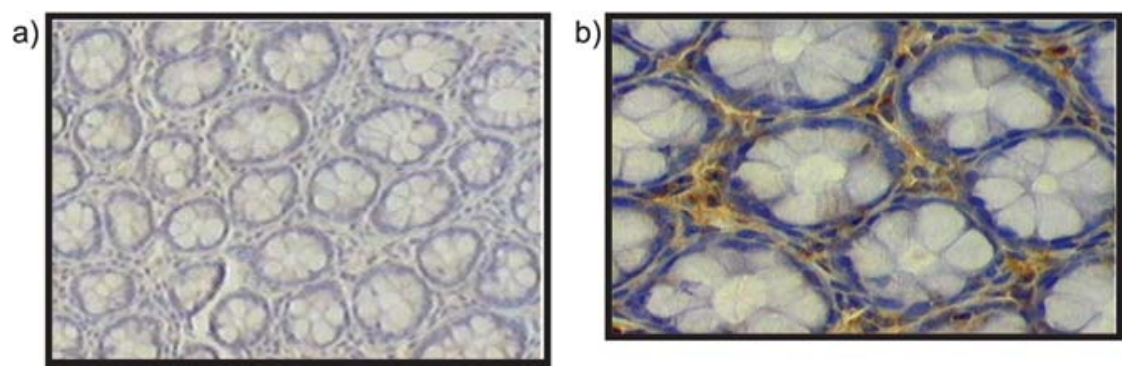

Figure 1 - Negative (A) and positive (B) example of the immunohistochemical reactions for TNF-D in rat colon - 400x
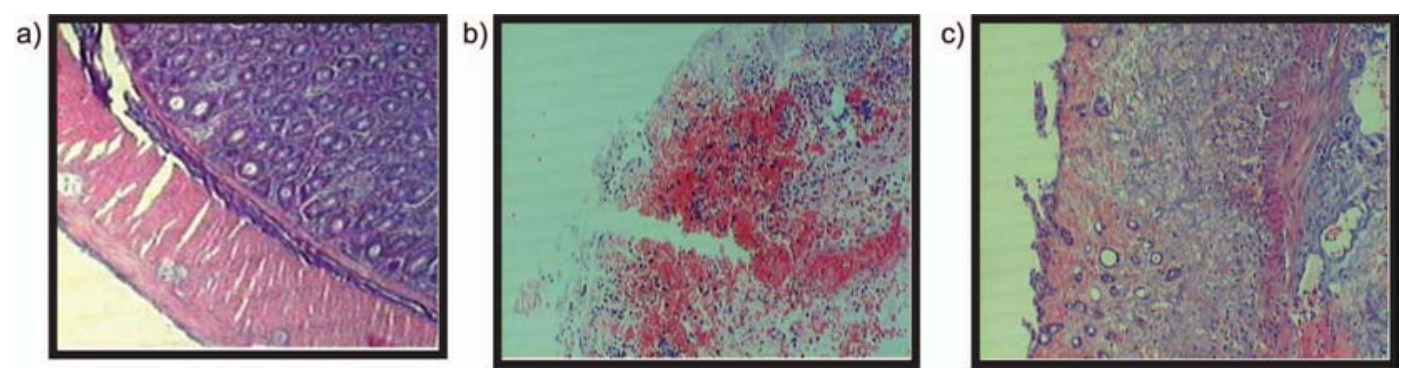

Figure 2 - Microscopic aspects with H \& E stain: A-normal mucosa; B-ulceration of colonic mucosa; and C-transmural necrosis 


\section{Statistical Analysis}

The results obtained were submitted to statistical analysis through the Student $t$ test for analysis of the macroscopic and microscopic variables and cytokine expression in the colonic mucosa, as well as the Fisher exact test to assess possible correlations between the cytokine expression and macroscopic alterations. The $95 \%$ significance level was adopted $(P<.05)$.

\section{RESULTS}

\section{Macroscopic alterations}

Macroscopic alterations of the abdominal cavity, such as adherences and distention of the intestinal loops and morphological signs of inflammation of the colonic mucosa and serosa, were only observed in the animals subjected to colitis. The macroscopic evaluation results for all groups are provided in Table 2 .

\section{Microscopic alterations}

The presence of inflammatory cells in the intestinal mucosa was observed in nearly all the animals subjected to

Table 2 - Classification of the abdominal cavity macroscopic alterations at sacrifice 45 minutes and 24 hours after inducing colitis

\begin{tabular}{lccccc}
\hline & \multicolumn{2}{c}{ Without colitis } & & \multicolumn{2}{c}{ With colitis } \\
\cline { 2 - 3 } \cline { 5 - 6 } & $45 \mathrm{~min}$ & $24 \mathrm{~h}$ & & $45 \mathrm{~min}$ & $24 \mathrm{~h}$ \\
\hline Gut Adherences & 0 & 0 & & 1 & 10 \\
Gut distention & 0 & 0 & & 3 & 4 \\
Hyperemia & 0 & 0 & & 5 & 2 \\
Ischemia with & 0 & & & & 7 \\
mucosal detachment & 0 & 0 & & 5 & 9 \\
Ulcer & & & & & 0 \\
\hline
\end{tabular}

experimental colitis, as well as in some animals without colitis. The most frequent microscopic alteration was evidence of focal reactional lymphoid hyperplasia. Exulceration, ulceration, and necrosis were observed exclusively in animals subjected to colitis (Table 3).

\section{Cytokine expression}

Data referring to cytokine expression for the various periods studied are shown in Table 4.

IL-1 presented increased expression in the group with colitis when compared to the groups without colitis after 24 hours.

In the colonic tissue of animals with colitis, expression of IL-4 was lower in the WC24 group when compared to the WC45 group.

There was a greater expression of IL-6 and INF-J in animals subjected to colitis when compared to the control groups, with no differences between the periods studied. The greater expression of INF-J and IL-6 in the presence of colitis was directly associated to the presence of necrosis in the colonic mucosa after the 24-hour period (Table 5).

TNF-D was the most frequently expressed cytokine in the colonic mucosa in the animals from the experimental

Table 3 - Classification of the microscopic alterations at sacrifice 45 minutes and 24 hours after inducing colitis

\begin{tabular}{lcccccc}
\hline & \multicolumn{2}{c}{ Without colitis } & & \multicolumn{2}{c}{ With colitis } \\
\cline { 2 - 3 } \cline { 5 - 6 } & $45 \mathrm{~min}$ & $24 \mathrm{~h}$ & & $45 \mathrm{~min}$ & $24 \mathrm{~h}$ \\
\hline Lymphoid hyperplasia & 5 & 8 & & 8 & 5 \\
$\begin{array}{l}\text { Exulceration } \\
\text { Ulcer }\end{array}$ & 0 & 0 & & 9 & 7 \\
Submucosa & 0 & 0 & & 1 & 8 \\
$\begin{array}{l}\text { inflammatory infiltrate } \\
\text { Muscular }\end{array}$ & 2 & & & & 8 & 9 \\
inflammatory infiltrate & 1 & & & & 2 & 6 \\
Transmural necrosis & 0 & 0 & & 0 & 4 \\
\hline
\end{tabular}

Table 4 - Distribution of mean cell positivity of cytokines (IL-1, 4, 6, TNF-D and IFN-J) in groups both with and without colitis at the different time periods of the experiment

\begin{tabular}{cccccc}
\hline Group & IL-1 & IL-4 & IL-6 & TNF-D & INF-J \\
\hline NC45 & $5.42 \pm 2.01$ & $8.81 \pm 3.85$ & $2.60 \pm 0.65$ & $15.74 \pm 9.25$ & $4.39 \pm 3.62$ \\
WC45 & $2.90 \pm 0.07$ & $11.05 \pm 1.91$ & $8.08 \pm 2.51$ & $14.50 \pm 8.58$ & $6.85 \pm 1.70$ \\
NC24 & $5.51 \pm 3.04$ & $6.33 \pm 0.84$ & $2.71 \pm 0.92$ & $15.78 \pm 5.70$ & $1.97 \pm 0.81$ \\
WC24 & $9.29 \pm 4.26$ & $7.92 \pm 3.90$ & $8.71 \pm 2.20$ & $16.55 \pm 7.21$ & $5.51 \pm 2.06$ \\
NC45 x WC45 & $* P=.0017$ & $P=.22$ & $* P=.0002$ & $P=.06$ & $* P=.03$ \\
NC24 x WC24 & $* P=.03$ & $P=.25$ & $* P £ .001$ & $P=.71$ & $* P=.0004$ \\
NC45 x NC24 & $P=.72$ & $P=.08$ & $P=.90$ & $P=.85$ & $P=0.06$ \\
WC45 x WC24 & $* P=.0014$ & $* P=.04$ & $P=.60$ & $P=.29$ & $P=.11$ \\
\hline
\end{tabular}

* $(P<.05)$ Student $t$ test; Data expressed as mean \pm standard deviation; Caption: WC45 = Group with colitis 45 minutes $(\mathrm{n}=10)$; NC45 = group without colitis 45 minutes $(\mathrm{n}=9)$; WC24 = Group with colitis 24 hours $(\mathrm{n}=10)$; NC24 = Group without colitis 24 hours $(\mathrm{n}=10)$ 
Table 5 - Association of necrosis and elevation of IFN-g and IL-6 for the group with colitis at 24 hours, submitted to the Fischer exact test

\begin{tabular}{lccccc}
\hline & \multicolumn{2}{c}{ IFN-J } & & \multicolumn{2}{l}{ IL-6 } \\
\cline { 2 - 3 } \cline { 5 - 6 } Necrosis & Elevated & Non-Elevated & & Elevated & Non-elevated \\
\hline Yes & $* 4$ & 0 & & $* 4$ & 0 \\
No & 0 & 6 & & 0 & 6 \\
\hline
\end{tabular}

* Fischer exact test: $P=.005$

groups as well as the control groups and for both periods studied.

\section{DISCUSSION}

One of the advantages of conducting studies in experimental models is the possibility of comparing controlled observations both before and after events, where clinical observation encounters ethical barriers. Wistar albino rats have been widely used in metabolism and nutrition studies $^{33-35}$ due to the ease in handling and follow-up.

The model of induced colitis through acetic acid enemas presents advantages over other experimental models of this disease. Such advantages include easy availability of the aggressor reagent, low cost, reproducibility and similarities to IID in humans, principally in terms of histological and metabolic aspects. ${ }^{13-15,17,18,35}$ However, little is known regarding its similarity in relation to the production of cytokines in the intestinal mucosa.

Cytokines can be quantified by various methods. Immunohistochemistry offers the advantage of directly demonstrating cells in the affected tissue that are secreting the cytokines under study. The advent of specific antibodies developed for immunohistochemical reactions, together with the standardization of a specific method to meet the objectives of the present study, permitted analysis of the production of various cytokines in the paraffin-embedded intestine samples.

The kinetics involved in the appearance of cytokines underlies the choice of different sacrifice times for the animals. After aggression, it was expected that the pro-inflammatory cytokines would increase in relation to the anti-inflammatory cytokines, presenting elevated peaks within very short periods of time. Later, the pro-inflammatory cytokines would progressively fall, giving rise to elevation of anti-inflammatory cytokines. ${ }^{36}$

Tissue analysis by immunohistochemical method enables the observation of cytokine expression in multiple points of different samples, comprising a broader evaluation and sometimes resulting in diverse profiles. The immunochemical assay may be repeated many times to confirm previous results.
Serum dosage of cytokine concentration is an accurate method but usually is not easily reproducible in the same sample and reflects only a single studied area.

Interleukins may be quantified by distinct methods, notably: radioimmunoassay (ELISA) performed in supernatant of cultured intestinal epithelial cells or portal and systemic blood, ${ }^{43}$ polymorphonuclear cultured cells stimulated by lipopolysaccharides, ${ }^{37-39}$ homogenized intestinal tissue, ${ }^{40} \mathrm{IL}$ cellular RNA quantification in intestinal samples and polymorphonuclear cells, ${ }^{39}$ immunohistochemical evaluation of IL, ${ }^{41,42}$ and DNA analysis after amplification of DNA content in damaged tissue. ${ }^{44}$

Any of the plasmatic IL quantification techniques may be criticized if sample collection or processing methods influence the expression of a given IL. Moreover, central vein blood samples may show an IL increase related to other inflammatory stimuli that are not necessarily related to bowel disease. It is recommended that the collection be done in the vicinity of the aggression. In humans with inflammatory bowel disease, portal vein samples would be ideal, ${ }^{43}$ although this presents technical difficulties.

Much effort has been made to standardize IL quantification methods. Colonic perfusion with a specific electrolyte solution enables intestinal lavage that shows suitable free IL dosage by ELISA. ${ }^{45,46}$

Immunohistochemical assay directly demonstrates the IL-expressing cells, but requires viable tissue samples. The plentiful availability of tissue from experimental models contrasts to the clinical scenario with limited samples from biopsies, which frequently are unsuitable for serial immunohistochemical reactions. ${ }^{44}$

In the present study, there was concern that necrosis, ulceration, or even detachment of the mucosa would be found in the area directly affected by the aggressor agent (acetic acid), depending on the local response with nonviable cells. After the immunohistochemical reactions, we analyzed a small number of cells that were expressing cytokines. We also analyzed a second fragment that was adjacent to the traumatized area in order to ensure that the basal membrane and lymphoid cells were intact and therefore expressing cytokines. Analysis by two different pathologists, blind to each other's findings, allowed us to avoid inadequate necrotic areas and to choose the most representative positive cells rather than false-positive granular histiocytes. Although computer-based image analyzers offer more accurate digital quantification, these are not available in many regional research centers, which are frequently understaffed and poorly equipped; consequently, we decided to establish a simple and reproducible method using only an optical microscope.

The groups with no colitis presented macroscopic and 
histological alterations of little biological significance. This was possibly due to local handling. The macroscopic study of abdominal and colonic lesions in the groups with colitis revealed severe alterations in comparison to the groups without colitis, and became progressively more intense with time (from $45 \mathrm{~min}$ to $24 \mathrm{~h}$ ).

Among the cytokines studied (IL-1, IL-4, IL-6, TNF-D, and IFN-J), TNF-D exhibited the highest levels of expression in all the groups and at both observation periods. The same has been demonstrated in another animal model, ${ }^{47}$ where the production of TNF-D and the mRNA for this cytokine were present in a model using macrophages from the lamina propria of the colon in mice that were not submitted to colitis. In the same study, after colitis was induced through TNBS, these macrophages increased the production of TNF-D from 10 to 30 times when compared to the controls, ${ }^{47}$ which was not observed in the present model of acetic acid induced colitis. In a similar manner, Hirata et al. ${ }^{48}$ failed to encounter an increased expression of TNF-D in the inflamed mucosa of rats with colitis induced through dextran sulfate. These observations indicate a possible influence of the aggressor agent over the type of cytokine response generated by the immune system of the intestinal mucosa in response to experimental colitis models; they are reproduced in the clinical environment ${ }^{49}$. While some investigators demonstrated increased levels of TNF-D in IID patients $^{50-52}$, others detected no increase in cytokine expression in such patients ${ }^{39}$.

Using experimental models to analyze cytokine expression, other investigators have reported an increase in TNF-D9. TNF-D is the first cytokine observed in any type of local aggression, with a measurable manifestation within a short period of time and peaking by 30 minutes. ${ }^{9}$ In the cytokine cascade sequence, TNF-D stimulates and raises the levels of IL-1 and IL-6. ${ }^{53,54}$ In our study, it is speculated that the surgical procedure involving catheter introduction could be responsible for elevated cellular TNF-D. In addition, although no was observed difference in TNF-D expression between the different groups, IL-1 and IL-6, together with IFN-J, presented elevated levels ( $45 \mathrm{~min}$ and $24 \mathrm{~h}$ post-infusion).

Our observations agree with the findings of Hirata et al., ${ }^{48}$ who observed an increase in IL-1 without an increase in TNF-D in the colonic mucosa of rats using a model of experimental colitis induced through dextran sulfate. Specifically in rela- tion to IL-1, the elevation in the expression of this cytokine in the colonic tissue after $24 \mathrm{~h}$ in the WC group can be considered pertinent, since IL-1 initiates expression at $60 \mathrm{~min}$ utes post-aggression, peaks from 6 to $12 \mathrm{~h}$, and can remain elevated for up to 7 days. ${ }^{9,55}$ Our data also corroborates the work by Khan et al., ${ }^{56}$ who described constitutive expression of RNAm for IL-1 in the colonic muscle of rats after endoanal infusion of acetic acid (4\%), which was significantly accentuated at 1,2 , and 5 days, returning to normal levels on day 7 after induction of the disease.

In the present study, a direct association was found between the presence of necrosis and the elevation of IL-6 and IFN-J pro-inflammatory cytokines. These data support the concept of efficacy of this colitis model as a means of reproducing observations made on inflammatory bowel disease in humans, where the increase of these cytokines is related to disease severity. ${ }^{57}$

In conclusion, the experimental model of acetic acid colitis promotes tissue aggression capable of causing the production of colonic cytokines. These cytokines exhibit a varied profile of expression in the colon and are similar to those found in lesions among inflammatory colitis patients, with an increase in the expression of pro-inflammatory cytokines. IL-6 and INF-J are adequate markers for the severity of acetic acid colitis and are related to the presence of necrosis in the colon. Immunohistochemical technique was efficient for the analysis of IL-1 pro-inflammatory cytokine expression, as well as IL-6 and IFN expression associated with the presence of colonic necrosis. This experimental model may be used in short- and long-term assessment of the behavior of different cytokines in different phases of colitis and potentially to assist in the development of "anti-cytokine" therapies to be used in the treatment of inflammatory bowel disease. Furthermore, prospective studies may include an approach involving computer analysis specially designed to provide the cytokine profile of inflammatory cells.

\section{ACKNOWLEDGEMENTS}

This work was supported by the CNPQ (process $n^{\circ}$ 140925/00-7) and Fapesp (process n ${ }^{\circ}$ 97/07971-70). The authors thank Laboratório de Patologia CLASSE I for immunohistochemical assay. 
Bertevello P, Logullo AF, Nonogaki S, Campos FM, Chiferi $\mathrm{V}$, Torrinhas CS et al. Avaliação imunohistoquímica do perfil citocínico da mucosa colônica em colite experimental induzida por ácido acético. Clinics. 2005;60(4):277-86.

O modelo de colite experimental induzida por ácido acético (CEAA) vem sendo extensamente utilizado em estudos sobre doenças inflamatórias intestinais (DII). Lesões no tecido colônico em portadores de DII parecem estar relacionados à produção local aumentada de citocinas próinflamatórias (IL-1, IL-6, TNF-De IFN-J ).

OBJETIVO: Avaliar o padrão de expressão de citocinas identificadas por imunohistoquímica em tecido colônico após CEAA e relacioná-lo à presença de lesões macroscópicas.

MATERIAL E MÉTODOS: Ratos machos Wistar adultos $(n=39)$ foram submetidos ou não à CEAA e sacrificados para retirada do tecido colônico em dois períodos distintos, perfazendo 4 grupos aleatórios: SC45 e SC24 (sem colite; sacrifício 45 minutos e 24 horas, respectivamente); CC45 e CC24 (com colite; sacrifício 45 minutos e 24 horas, respectivamente). Avaliaram-se alterações macro e microscópicas do cólon e sua expressão de citocinas foi avaliada por imunohistoquímica.

RESULTADOS: Após 24 horas, a expressão de IL-1 foi maior no grupo com colite, em relação ao sem colite. IL-4 foi mais expressa no grupo CC45. Houve aumento de INF-J e IL-6, relacionados à presença de necrose da mucosa colônica, nos grupos com colite, em ambos os períodos avaliados.

CONCLUSÃO: A técnica de imunohistoquímica foi eficiente para a análise da expressão de citocinas na mucosa colônica. Houve aumento da expressão das citocinas pró-inflamatórias IL-1 e de IL-6 e IFN-J associado à presença de necrose colônica. A CEAA é um bom modelo para o desenvolvimento de estudos destinados a avaliar o papel das citocinas na inflamação da mucosa e terapias anti-citocinas.

UNITERMOS: Citocinas. Ratos. Colite inflamatória. Imunohistoquímica. Necrose.

\section{REFERENCES}

1. Sartor RB. Cytokines in intestinal inflammation: pathophysiologic and clinical considerations. Gastroenterology. 1994;106(2):533-9.

2. Elson CO, Sartor RB, Tennyson G, Riddel R. Experimental models of IBD. Gastroenterology. 1995;109(4):1344-67.

3. Braegger CP, MacDonald TT. Immune mechanisms in chronic inflammatory bowel disease. Ann Allergy. 1994;72(2):135-41.

4. Autschbach F, Schürmann G, Qiao L, Merz H, Wallich R, Meuer SC. Cytokines messenger-RNA expression and proliferation status of intestinal mononuclear cells in noninflamed gut and Crohn's disease. Virchows Arch. 1995; 426(1):51-60

5. Murata Y, Ishiguro Y, Itou J. The role of proinflammatory and immunoregulatory cytokines in the pathogenesis of ulcerative colitis. Gastroenterol. 1995;30(8):56-60.

6. Casini-Raggi V, Kam L, Chong YIT, Fiocchi C, Pizarro TT, Cominelli F. Mucosal imbalance of IL-1 and IL-1 receptor antagonist in inflammatory bowel disease: a novel mechanism of chronic intestinal inflammation. J. Immunol. 1995;154(5):2434-40.

7. Andus T, Daig R, Lock G, Hollerbach S, Caesar I, Vogl D, et al. Balance between pro and anti-inflammatory cytokines in the colonic mucosa in inflammatory bowel diseases (IBD). Gastroenterology. 1995;108:A770.

8. Andus T, Vogl D, Aschenbrenner E, Kollinger M, Scholmerich J, Gross V. IL-1ra genotype 2 is associated with reduced IL-1ra in colonic mucosa. Gastroenterology. 1996;110:A855.
9. Tateishi H, Mitsuyama K, Toyonaga A, Tomoyose M, Tanikawa K. Role of cytokines in experimental colitis: relation to intestinal permeability. Digestion. 1997;58(3):271-81.

10. Van Deventer SJ. Cytokines and mucosal inflammatory response in Crohn's disease. Eur J Surg. 1998;164(12):897-901.

11. Onderdonk AB. Experimental models for ulcerative colitis. Dig Dis Sci. 1985;30(12):405-445.

12. Macpherson BR, Pfeiffer CJ. Experimental production of diffuse colitis in rats. Digestion. 1978;17(2):135-50.

13. Sharon P, Stenson WF. Metabolism of arachidonic acid in acetic acid colitis in rat: similarity to human inflammatory bowel disease. Gastroenterol. 1985;88(1):55-63.

14. Moraes RS. Indução da colite difusa pela instilação de ácido acético via retal: estudo experimental em ratos Sprage-Dawley [dissertação]. Curitiba (PR): Faculdade de Medicina da Universidade Federal do Paraná;1987.

15. Moraes RS. Aspectos morfológicos da colite induzida pelo ácido acético $10 \%$ e tratada com enemas de ácido 5-amino-2hidroxibenzóico. Estudo experimental em ratos Sprage-Dawley [dissertação]. São Paulo (SP): Escola Paulista de Medicina, Universidade Federal de São Paulo; 1989.

16. Thomas TK, Will PC, Srivastava A, Wilson CL, Harbison M, Little J. Evaluation of an interleukin-1 receptor antagonist in the rat acetic acid-induced colitis model. Agent Actions. 1991;34(1-2):187-90. 
17. Lowe VC, Noronha-Blob L. The leukocyte recruitment inhibitor, NPC 15669 accelerates healing in acetic acid-induced colitis. Agents Actions. 1993;39:C80-2.

18. Campos FG, Waitzberg DL, Logulo AF, Cukier C, Soares Sr, Oliveira TS, et al. Padronização técnica e histológica de colite experimental com ácido trinitrobenzenosulfônico (TNBS). Rev Hosp Clin Fac Med S Paulo. 1997;52(4):180-86.

19. Wallace JL, Whitle BJ, Bought-Smith NK. Prostaglandin protection of rat colonic mucosa from damage induced by ethanol. Dig Dis Sci. $1985 ; 30(9): 866-76$.

20. Psaila JV, Myers B, Jones IR, Rhodes J. Effect of prostaglandin PGE-2 on alcohol-induced ulceration in the rat colon. Digestion. 1986;35(4):224-8.

21. Marotta F, Chui DH, Safran P, Rezakovic I, Zhong GG, Ideo G. Shark fin enriched diet prevents mucosal lipid abnormalities in experimental acute colitis. Digestion. 1995;56(1):46-51.

22. Stewart THM, Hetenyi C, Rowsell H, Orizaga M. Ulcerative enterocolitis in dog induced by drugs. J Pathol. 1980;131(4):363-78.

23. Morris GP, Beck PL, Herridge MS, Depew WT, Szewczuk MR, Wallace JL. Hapten-induced model of chronic inflammation and ulceration in the rat colon. Gastroenterol. 1989;96(3):795-803.

24. Shoda R, Matsueda K, Yamato S, Umeda N. Therapeutic efficacy of n-3 polyunsaturated fatty acid in experimental Crohn's disease. J Gastroentrol. 1995;30(8):98-101.

25. Inui K, Fukuta Y, Ikeda A, Kameda H, Kokuba Y, Sato M. The effect of alpha-linolenic acid-rich emulsion on fatty acid metabolism and leukotriene generation of the colon in a rat model with inflammatory bowel disease. Ann Nutr Metab. 1996a;40(3):175-82.

26. Inui K, Fukuta Y, Kameda H, Kokuba Y, Sato M. The nutrition effect of a-linolenic acid-rich emulsion with total parenteral nutrition in a rat model with inflammatory bowel disease. Ann Nutr Metab. 1996b;40(4):227-33.

27. Murthy SN, Fondacaro JD, Murthy NS, Bolkenius F, Cooper HS. Effects of MDL 73404 (MDL) in experimental murine colitis [abstract]. Gastroenterology. 1995;104:A752.

28. Pfeiffer CJ, Qui BS. Recombinant human interleukin-11 decreases trinitrobenzene sulfonic acid-induced colitis in rats. Gastroenterology. 1995;108:A893.

29. Albert LM, Ferranti TJ, Erickson JE, Donelly LH, Schaub RG, Keith JC. Dose response and schedule studies of recombinant human interleukin-11 in acetic acid induced colonic injury in rats. Gastroenterology. 1995;108:A768.

30. Strober W. Animal models of inflammatory bowel disease-an overview. Dig Dis Sci. 1985;30(12):3-10.

31. Madara JL, Stafford J. Interferon-g directly affects barrier function of cultured intestinal epithelial monolayers. J Clin Invest. 1989;83(2):724-7.

32. Mullin JM, Snock KV. Effect of tumor necrosis factor on epithelial tight junctions and transepithelial permeability. Cancer Res. $1990 ; 50(7): 2172-6$.
33. Waitzberg DL, Gonçalves EL, Yamagushi N, Bellinati-Pires R, Leone MC, Marili-Okusm, et al. Survival, bacterial clearance and polymorphonuclear cells function in septic rats infused with LCT and MCT/LCT emulsions. Clin Nutr. 1991;10(2):58-62.

34. Cukier C, Waitzberg DL, Logullo AF, Bacchi CE, Travassos VH, Torrinhas RS, et al. Lipid and lipid-free total parenteral nutrition: differential effects on macrophage phagocytosis in rats. Nutrition. 1999;15(11-12):885-9.

35. Campos FG, Waitzberg DL, Habr-Gama A, Logullo AF, Noronha IL, Jancar S, et al. Impact of parenteral n-3 fatty acids on experimental acute colitis. Br J Nutr. 2002;87(1):S83-S88.

36. Mayer K, Seeger W, Grimminger F. Clinical use of lipids to control inflammatory disease. Curr Opin Clin Nutr Metab Care. 1998;1(2):179-84.

37. Mahida YR, Wu K, Jewell DP. Enhanced production of interleukin$1 \mathrm{~b}$ by mononuclear cells isolated from mucosa with active ulcerative colitis and Crohn's disease. Gut. 1998;30:835-8.

38. Macdonald TT, Hutchings P, Choy MY, Murch S, Cooke A. Tumor necrosis factor-alpha and interferon-gamma production measured at the single cell level in normal and inflamed human intestine. Clin Exp Immunol. 1990;81:301-5.

39. Youngman KR, Simon PL, West GA, Cominelli F, Rachmilewitz D, Klein JS, Fiocchi C. Localization of intestinal interleukin 1 activity and protein and gene expression to lamina propria cells. Gastroenterology. 1993;104:749-58.

40. Mitsuyama K, Saaki E, Toyonaga A, Ikeda H, Tsuruta O, Irie A, et al. Colonic mucosal interleukin-6 in inflammatory bowel disease. Digestion. 1991;50:104-11.

41. Stevens C, Waltz G, Singaram C, Lipman ML, Zanker B, Muggia A, et al. Tumor necrosis factor-a, interleukin-1b, and interleukin6 expression in inflammatory bowel disease. Dig Dis Sci. 1992;37:818-26.

42. Murch SH, Braegger CP, Walker-Smith JA, Macdonald TT. Location of tumor necrosis factor a by immuno-histochemistry in chronic inflammatory bowel disease. Gut. 1993;34:1705-9.

43. Tateishi H, Mitsuyama K, Toyonaga A, Tomoyose M, Tanikawa K. Role of cytokines in experimental colitis: Relation to intestinal permeability. Digestion. 1997;58:271-81.

44. Funakoshi K, Sugimura K, Anezaki K, Bannai H, Ishizuka K, Asakura H. Spectrum of cytokine gene expression in intestinal mucosal lesions of Crohn's disease and ulcerative colitis. Digestion. 1998;59:73-78.

45. Guimbaud R, Izzo A, Martinolle P. Intraluminal excretion of Paf, lysoPaf and acetylhydrolase in patients with ulcerative colitis. Dig Dis Sci. 1995;40:2635-40.

46. Guimbaud R, Bertrand V, Chauvelot-Moachon L, Quartier G, Vidon $\mathrm{N}$, Giroud JP, et al. Network of inflammatory cytokines and correlation with disease activity in ulcerative colitis. Am J Gastroenterol. 1998;93:2397-404.

47. Neurath MF, Fuss I, Kelsall BL, Stuber E, Strober W. Antibodies to interleukin-12 abrogate established experimental colitis in mice. J Exp Med. 1997;182(5):1281-90. 
48. Hirata I, Murano M, Nitta M, Sasaki S, Toshina K, Maemura K, et al. Estimation of mucosal inflammatory mediators in rat DSSinduced colitis. Possible role of PGE2 in protection against mucosal damage. Digestion. 2001;63(1):63-80

49. Rogler G, Andus T. Cytokines in inflammatory bowel disease. World J Surg 1998;22(4):382-9.

50. Maeda M, Watanabe N, Neda H, Yamauchi N, Okamoto T, Sasaki $\mathrm{H}$, et al. Serum tumor necrosis factor activity in inflammatory bowel disease. Immunopharmacol. Immunotoxicol. $1992 ; 14(3): 451-61$.

51. Braegger CP, Nicholls S, Murch SH, Stephens S, MacDonald TT. Tumour necrosis factor alpha in stool as a marker of intestinal inflammation. Lancet. 1992;339(8785):89-91.

52. Andus T, Targan SR, Deem R, Toyoda H. Measurement of tumor necrosis factor alpha mRNA in small numbers of cells by quantitative polymerase chain reaction. Reg Immunol. 1993;5(1):11-7.53. Dinarello CA, Cannon JG, Wolff SM, Bernheim HA, Beutler B, Cerami A, et al. Tumor necrosis factor (cachectin) is an endogenous pyrogen and induces production of interleukin-1. J Exp Med. 1986;163(6):1433-50.
54. Kohase M, Destefano DH, May LT, Vilcek J, Sehgal PB. Induction of beta 2-interferon by tumor necrosis factor. A homeostatic mechanism in the control of cell proliferation. Cell. 1986;45(5):659-66.

55. Rachmilewitz D, Simon PL, Schwartz LW, Griswold DE, Fondacaro JD, Wasserman MA. Inflammatory mediators of experimental colitis in rat. Gastroenterology. 1989;97(2):326-37.

56. Khan I, Al-Awadi FM. Colonic muscle enhances the production of interleukin-1 beta messenger RNA in experimental colitis. Gut. $1997 ; 40(3): 307-312$

57. Gotteland M, Saenz R, Lopez M, Altshiller H, Llorens P, Brunser O. Interleukin-6 and Interferon-gamma release from blood mononuclear cells and colonic mucosa from patients with ulcerative colitis. Rev Med Chil. 1998;126(9):1043-8. 